\title{
Effects of malonic acid on calcium carbonate crystalline phases and morphology
}

\author{
S. Muryanto ${ }^{1}$ \\ Department of Chemical Engineering \\ UNTAG University in Semarang \\ Semarang, Indonesia \\ ${ }^{1}$ stmuryanto@untagsmg.ac.id \\ S. Sutanti \\ Politeknik Katolik Mangunwijaya \\ Semarang, Indonesia
}

\author{
E. Supriyo \\ Chemical Engineering Vocational School \\ Diponegoro University \\ Semarang, Indonesia \\ W.A. Putranto \\ Politeknik Maritim Negeri Indonesia \\ Semarang, Indonesia
}

\begin{abstract}
Industrial applications of calcium carbonate $\left(\mathrm{CaCO}_{3}\right)$ is dictated by its crystal properties. To a large extent, $\mathrm{CaCO}_{3}$ scaling which is prevalent in industrial equipment is also governed by such properties. Detailed understanding of alteration of $\mathrm{CaCO}_{3}$ properties is therefore of prime importance. This paper reports $\mathrm{CaCO}_{3}$ precipitation conducted by drop-wise addition of $\mathrm{Na}_{2} \mathrm{CO}_{3}$ solution into solution of $\mathrm{CaCl}_{2}$ with stirring. The precipitation was done with and without malonic acid. Precipitates were filtered, centrifuged, and oven dried overnight at $60^{\circ} \mathrm{C}$. The samples were characterized using SEM, XRD, and FTIR. In all cases amorphous calcium carbonate precipitated first and with time it transformed into calcite via vaterite and aragonite. It was found that malonic acid was able induce vaterite growth in solution. Higher amounts of malonic acid (ppm amounts) resulted in more vaterite phase alongside calcite. Both calcite and vaterite morphology changed with malonic acid in the solution as compared with pure precipitation with the acid.
\end{abstract}

Keywords- $\mathrm{CaCO}_{3}$; crystal phases; malonic acid; scale control

\section{INTRODUCTION}

Calcium carbonate $\left(\mathrm{CaCO}_{3}\right)$ crystals have wide industrial applications, and each application requires certain crystalline phase and morphology. $\mathrm{CaCO}_{3}$ is also one of the main components of scale which can develop in industrial equipment, particularly in the piping system and heat exchangers. The properties of the scale is often dictated by the phases and morphological nature of the crystals [1]. Under ambient conditions and in a pure precipitation system the crystalline carbonate mineral comprises three anhydrous crystalline polymorphs: vaterite, aragonite, and calcite, and two hydrous crystalline forms: $\mathrm{CaCO}_{3} \cdot \mathrm{H}_{2} \mathrm{O}$, and $\mathrm{CaCO}_{3} \cdot 6 \mathrm{H}_{2} \mathrm{O}$ [2, 3]. Additionally, there is one non-crystalline, i.e amorphous calcium carbonate (ACC) which is hydrous and normally precipitates first in the system [4]. A number of studies have been conducted on the phenomenon of phase change from vaterite and aragonite which transformed into calcite $[5,6]$.

Morphologies of $\mathrm{CaCO}_{3}$ vary widely and extensive research have been carried out to mimic such variations either by the assistance of templates, additives, or manipulation of precipitation conditions [7-11].
Organic compounds are known to effectively modify crystal structure, morphology and properties of $\mathrm{CaCO}_{3}$ crystals. The growth kinetics of $\mathrm{CaCO}_{3}$ under the influence of organic compounds is therefore an area of intensive research [10, 12, 13]. When properly applied, an organic anti-scalant has the advantage of effectively inhibiting scale formation at very low dosages, typically below $30 \mathrm{ppm}$. A number of organic additives, especially of carboxylic species, were shown to substantially suppress carbonate mineral precipitation and its practical application in scale control has been confirmed $[3,5$, 14-22].

This paper discusses the modification of the three wellknown crystalline phases of $\mathrm{CaCO}_{3}$, namely vaterite, aragonite, and calcite which was precipitated under the influence of malonic acid. Malonic acid was selected as additive since it is a di-carboxylic acid and is frequently found as trace component in the wastewater of fruit canning industries.

\section{EXPERIMENTAL}

\section{A. Preparation}

The precipitation was carried out batch-wise using $0.5 \mathrm{M}$ $\mathrm{CaCl}_{2}$ and $0.5 \mathrm{M} \mathrm{Na}_{2} \mathrm{CO}_{3}$ solutions, following the reaction as follows:

$$
\mathrm{CaCl}_{2}+\mathrm{Na}_{2} \mathrm{CO}_{3} \rightarrow \mathrm{CaCO}_{3}+2 \mathrm{NaCl}
$$

Malonic acid $\left[\mathrm{CH}_{2}(\mathrm{COOH})_{2}\right]$, in the form of a weak solution, was added into the precipitating carbonate solution in varied ppm quantities. The crystals obtained from the precipitation were characterized using SEM-EDX, XRD and FTIR

In a typical synthesis, eight precipitation runs were carried out as follows. The solutions of $\mathrm{CaCl}_{2}(50 \mathrm{mM}, 50 \mathrm{~mL})$ and $\mathrm{Na}_{2} \mathrm{CO}_{3}(50 \mathrm{mM}, 50 \mathrm{~mL})$ were quickly mixed in a $200-\mathrm{mL}$ beaker with rigorous stirring which continued for two minutes. Then the beakers were sealed and allowed to stand undisturbed at room temperature. As arranged for the experimental design, the beakers were separately decanted after a pre-determined time period: $5 \mathrm{~min}, 10 \mathrm{~min}, 20 \mathrm{~min}, 30 \mathrm{~min}, 1 \mathrm{~h}, 2 \mathrm{~h}, 6 \mathrm{~h}, 48 \mathrm{~h}$. 
Similar experiments were conducted with the addition of malonic acid solution. The precipitates were washed thoroughly with distilled water, and then dried in a vacuum oven at $60^{\circ} \mathrm{C}$ overnight. The dried precipitates were stored in vials for subsequent analysis.

\section{B. Characterization}

The morphology of the crystals obtained was characterized by scanning electron microscopy (SEM) with an accelerating voltage of $30 \mathrm{kV}$ (FEI - Inspect-S-50). The SEM was coupled with an energy dispersive spectroscopy (EDS) system. For these observations the samples were embedded in epoxy on glass slides. The prepared samples were then sputtered with $\mathrm{Au}$ for SEM analysis.

The samples were also subjected to X-ray diffraction (XRD) analysis. They were ground with a mortar and pestle. These specimens were then manually front-loaded into a plastic well mounted by lightly pressing with a glass slide. Next, data collection for crystal phase identification were performed to determine the identity of the crystalline phase. The peak positions and peak heights were checked against the data of the standard spectrum for $\mathrm{CaCO}_{3}$ (JCPDS - \#47-1743).

To identify that the functional groups of the malonic acid involved in the precipitation process, an FTIR analysis was conducted (Shimadzu - IR-Prestige-21).

\section{RESULTS AND DISCUSSION}

\section{A. SEM-EDX Analysis}

SEM analysis indicates the morphological changes as affected by the experimental conditions: precipitation times and amount of malonic acid added.

Under pure system, when no additive were added, and ambient conditions, the presence of all three phases: vaterite, aragonite, and calcite was evident (Fig 1). On the other hand, when ppm amounts of malonic acid were added the formation of vaterite and aragonite was less dominant compared to that of calcite (Fig 2). It was postulated that the malonic acid functional groups may have suppressed the nucleation or retarded the growth of vaterite and aragonite. Such suppression and retardation can be due to the complexation of $\mathrm{Ca}^{2+}$ with functional groups of malonic acid, hence reducing the amount of $\mathrm{Ca}^{2+}$ required for nucleation and growth.

Comparison of longer precipitation times both in the absence (Fig 3) and in the presence (Fig 4) of malonic acid reveals that malonic acid may have interfered with nucleation and growth as stated previously. Complexation of carboxylic functional groups with $\mathrm{Ca}$ ions [23] reduces the saturation levels for the formation of $\mathrm{CaCO}_{3}$. This may explain the prolongation of the life time of the unstable phases: either vaterite or aragonite, as can be seen in Fig 4 to achieve the final and stable phase of calcite. On the other hand, a much shorter precipitation time with no additive has resulted in the attainment of the stable phase: calcite (Fig 3). That the complexation of Ca-malonic acid took place can also be confirmed by the FTIR data. As can be seen (Fig 10), the FTIR show peaks of malonic acid components that may have attached or reacted on the surface of $\mathrm{CaCO}_{3}$.

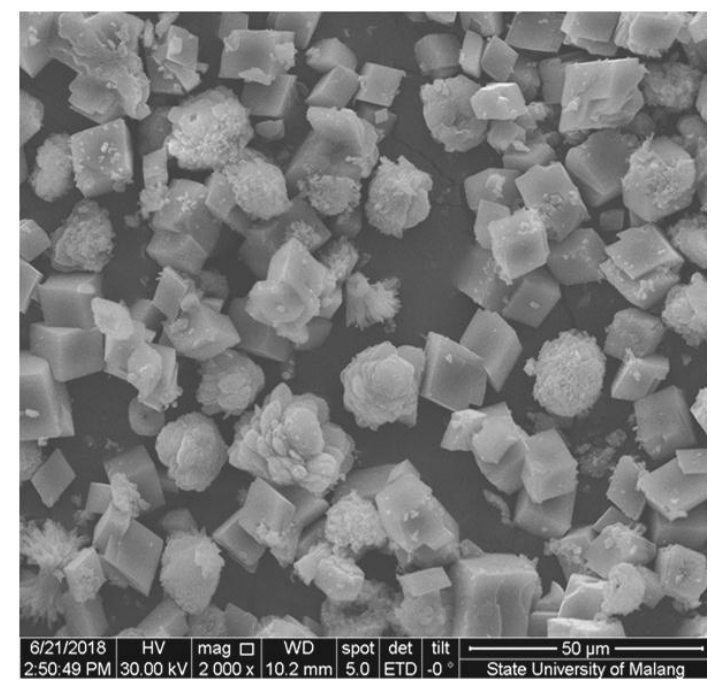

Fig. 1. SEM graph of $\mathrm{CaCO}_{3}$ crystals in a pure system after $4 \mathrm{~min}$

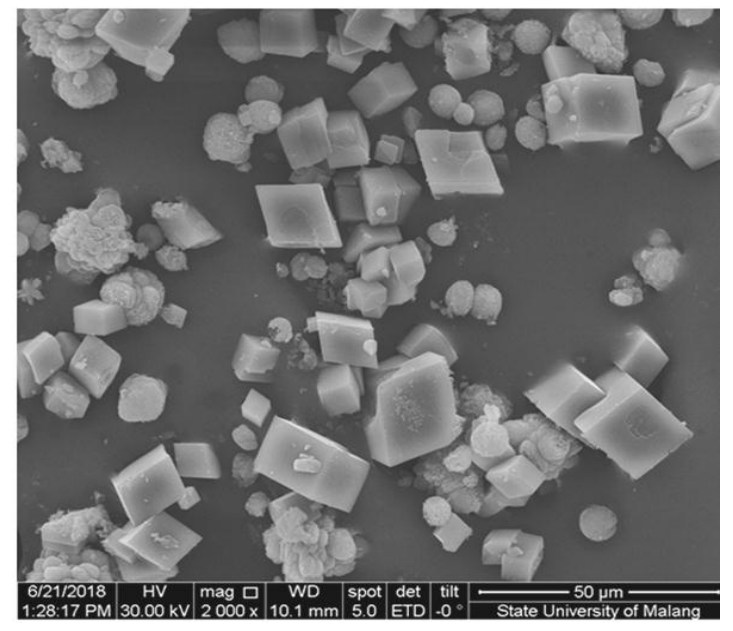

Fig. 2. SEM graph of $\mathrm{CaCO}_{3}$ with 20 ppm malonic acid after $4 \mathrm{~min}$

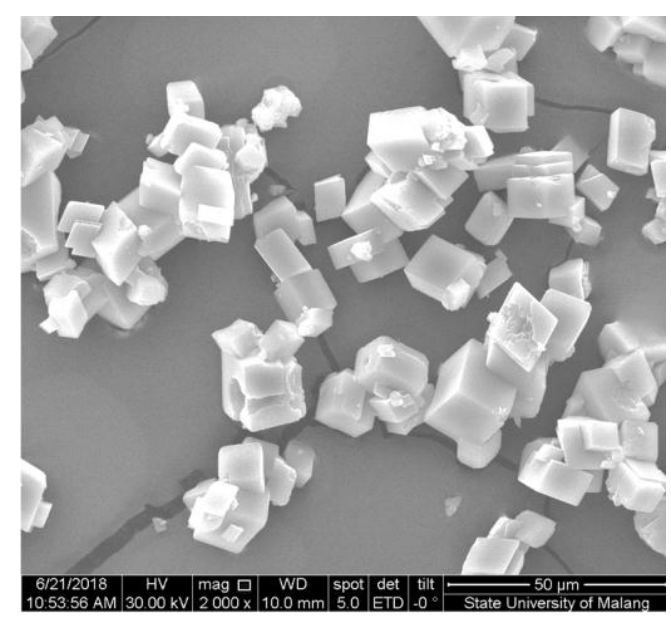

Fig. 3. SEM graph of $\mathrm{CaCO}_{3}$ crystals in a pure system after six hours 


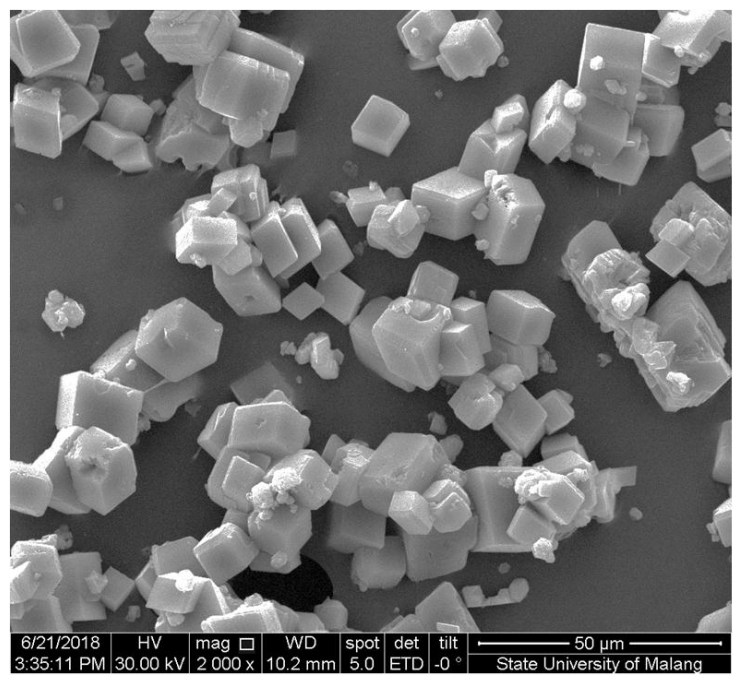

Fig. 4. SEM graph of $\mathrm{CaCO} 3$ with 20 ppm malonic acid after 48 hours

\section{B. X-Ray Diffraction}

The XRD spectra show the difference in the amount of the crystalline phases (Figs 5 and 6). In the pure system the percentage of the three polymorphs is: $\mathrm{V}=14.59 \%, \mathrm{~A}=1.72 \%$, and $\mathrm{C}=83.69 \%$, respectively (Fig 5). In contrast, under the influence of $30.00 \mathrm{ppm}$ malonic acid the corresponding values are: $49.10 \%, 0.00 \%$, and $50.90 \%$, respectively (Fig 6). These data indicate the retarding effect of malonic acid on the transformation toward the stable phase, i.e calcite. The ppm amounts of malonic acid under the current experimental conditions have been able to retard the progress toward the stable phase by as much as $32.79 \%$. The transformation is also visually shown in Figs 7 and 8.

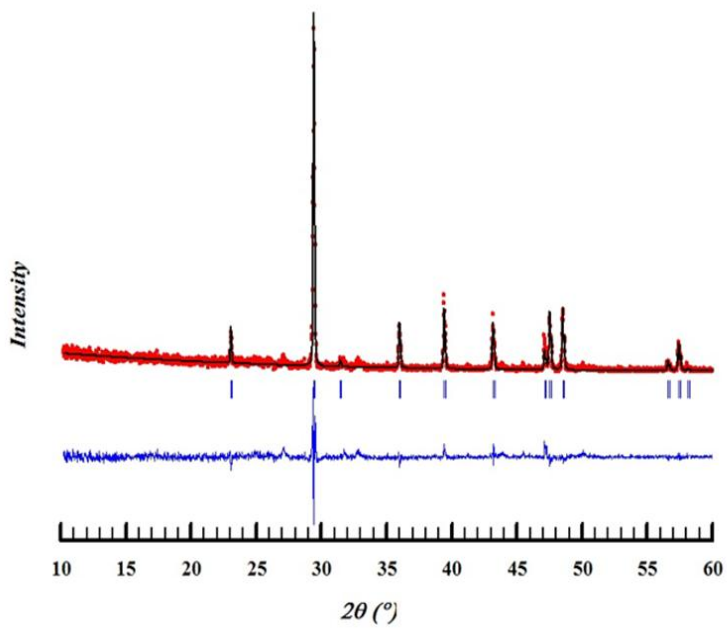

Fig. 5. XRD of $\mathrm{CaCO} 3$ precipitated after $5 \mathrm{~min}$ without malonic acid

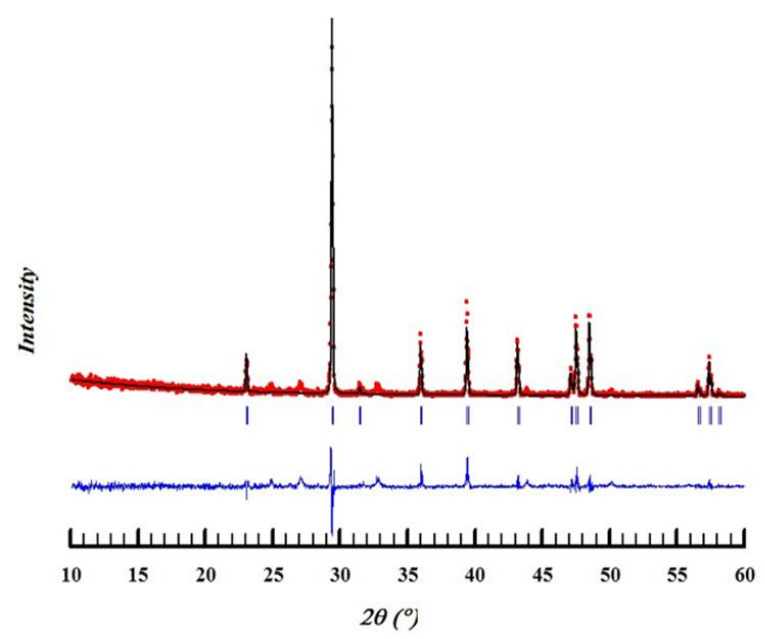

Fig. 6. XRD of $\mathrm{CaCO}_{3}$ precipitated after 5 min with 20.00 ppm malonic acid.

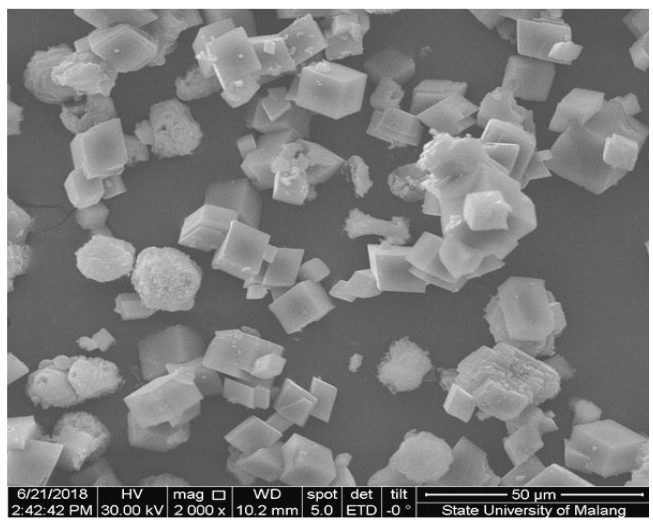

Fig. 7. SEM of $\mathrm{CaCO}_{3}$ precipitated after $5 \mathrm{~min}$ without malonic acid

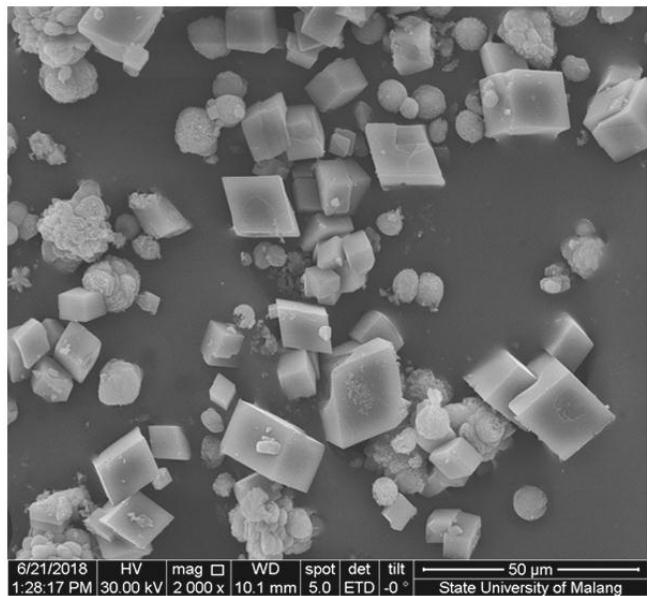

Fig. 8. SEM of $\mathrm{CaCO}_{3}$ precipitated after 5 min with $20.00 \mathrm{ppm}$ malonic acid showing less calcite.

\section{FTIR}

The FTIR spectra comparing the pure system and that under malonic acid are shown below (Figs 9 and 10).

The FT-IR spectra of the samples show a sharp peak at $873.68 \mathrm{~cm}^{-1}$ which corresponds to the out-of-plane bending 
vibration ( $\left.\mathrm{v}_{2}\right)$ of carbonate, while another sharp peak observed at $711.73 \mathrm{~cm}^{-1}$ corresponds to the in-plane bending vibration of carbonate[24] These two peaks are characteristics of calcite. Further, two peaks appearing at 1083.99 and 1166.93 can be assigned to aragonite. Further, the sharp peak appears at 416.62 $\mathrm{cm}^{-1}$ can be assigned to $\mathrm{Ca}-\mathrm{O}$ bond [25]

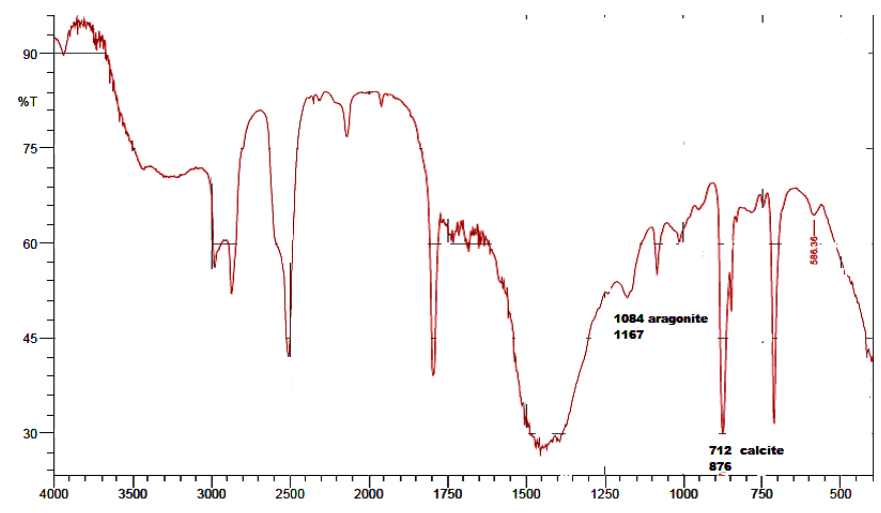

Fig. 9. FTIR of the sample without malonic acid

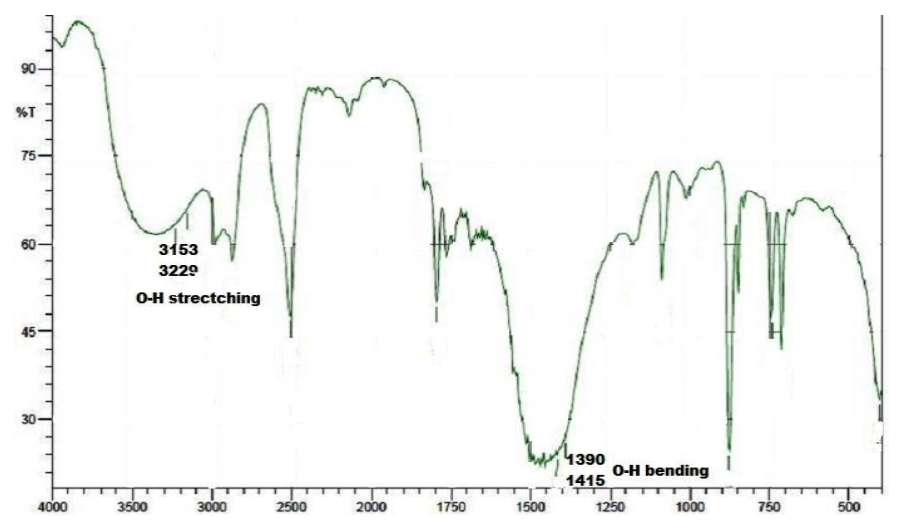

Fig. 10. FTIR spectra of the samples with malonic acid (see peaks for O-H strectching and bending, respectively)

\section{CONCLUSION}

The present study shows that malonic acid in trace amounts was able to influence the precipitation of calcium carbonate, in terms of crystalline phases and morphology. The di-carboxylic acid used was able to suppress the nucleation and growth of $\mathrm{CaCO}_{3}$, since the functional groups of the acid formed complexation with $\mathrm{Ca}$ ions and thus reducing the saturation levels of the precipitating solution. Low saturation results in less nucleation and growth.

\section{ACKNOWLEDGMENT}

The authors (SM, SS, ES) are grateful to the Ministry of Research, Technology and Higher Education of the Republic of Indonesia for funding the current work through the PDUPT grant: B.09/01.011/KP-PDUPT/III/2018.

\section{REFERENCES}

[1] S. Muryanto and A.P. Bayuseno, "Influence of $\mathrm{Cu}^{2+}$ and $\mathrm{Zn}^{2+}$ as additives on crystallization kinetics and morphology of struvite," Powder Technol., vol. 253, pp. 602-607, 2014.

[2] L. Addadi, S. Raz, and S.Weiner, "Taking advantage of disorder: amorphous calcium carbonate and its role in biomineralization," Adv. Mater., vol. 15, no. 12, pp. 959 - 970, 2003.

[3] H. Keller and J. Plank, "Mineralisation of $\mathrm{CaCO}_{3}$ in the presence of polycarboxylate comb polymers", Cem. and Concr. Res., vol. 54, pp. 111, 2013.

[4] F.M. Michel et al., "Structural characteristics of synthetic amorphous calcium carbonate," Chem. of Mater., vol. 20, pp.4720 - 4728, 2008.

[5] D.J. Tobler et al., "Citrate effects on amorphous calcium carbonate (ACC) structure, stability, and crystallization," Adv. Funct. Mater., vol. 25, pp. 3081-3090, 2015.

[6] T. Ogino, T. Suzuki, and K. Sawada, "The rate and mechanism of polymorphic transformation of calcium carbonate in water," J. of Cryst. Growth, vol. 100, pp. 159 - 167, 1990.

[7] S.F. Chen, S.H. Yu, J. Jiang, F.Q. Li, and Y.K. Liu, "Polymorph discrimination of $\mathrm{CaCO}_{3}$ mineral in an ethanol/water solution: formation of complex vaterite superstructures and aragonite rods," Chem. of Mater., vol. 18 , pp. 115-122, 2006.

[8] H. Colfen, "Precipitation of carbonates: recent progress in controlled production of complex shapes," Curr. Opin. in Colloids and Interface Sci., vol. 8, pp. 23-31, 2003.

[9] Y.S. Han, G. Hadiko, M. Fuji, and M. Takahashi, "Crystallization and transformation of vaterite at controlled $\mathrm{pH}$," J. of Crystal Growth, vol. 289, pp.269-274, 2006.

[10] F.C. Meldrum and H. Colfen, "Controlling mineral morphologies and structures in biological and synthetic system," Chem. Reviews, vol. 108, pp. 4332-4432, 2008.

[11] N.A.J.M. Sommerdijk and G. de Wit, "Biomimetic $\mathrm{CaCO}_{3}$ mineralization using designer molecules and interfaces," Chem. Rev., vol. 108, pp. 4499 4550, 2008.

[12] J.D. Rodriguez-Blanco, S. Shaw, P. Bots, T. Roncal-Herrero, and L.G. Benning, "The role of $\mathrm{Mg}$ in the crystallization of monohydrocalcite," Geochim. et Cosmochim. Acta., vol. 127, pp. 204 - 220, 2015.

[13] J. Ihli, Y.Y. Kim, E.H. Noel, and F.C. Meldrum. "The effect of additives on amorphous calcium carbonate (ACC): Janus behavior in solution and the solid state," Adv. Funct. Mater., vol. 23, no. 12, pp. 1575-1585, 2013.

[14] N.M. Kumar, S.K. Gupta, D. Jagadeesh, K. Kanny, and F. Bux, "Development of poly(aspartic acid-co-malic-acid) composites for calcium carbonate and sulphate scale inhibition," Environ. Technol., vol. 36, pp. 1281-1290, December 2014.

[15] V.M. Rosas-García, I. de León-Abarte, G. Vidal-López, A. PalaciosPargas, and X. Jáuregui-Prado, "Not all carboxylates are created equal: differences in interaction of carboxylated peptides with a $\mathrm{CaCO}_{3}$ dimer," Biophys. Chem., vol. 192, pp. 27-32, 2014.

[16] R.A. Metzler et al., "Probing the organic-mineral interface at the molecular level in model biominerals," Langmuir., vol. 24, pp. 26802687, 2008.

[17] E. Yoğurtcuoğlu, and M. Uçurum, "Surface modification of calcite by wet-stirred ball milling and its properties," Powder Technol., vol. 214, pp. 47-53, 2011.

[18] M. Karimi, R.S. Al-Maamari, S. Ayatollahi, and N. Mehranbod, "Mechanistic study of wettability alteration of oil-wet calcite: the effect of magnesium ions in the presence and absence of cationic surfactant," Colloids and Surf.: A Physicochem. Eng. Asp., vol. 482, pp. 403-415, 2015.

[19] H.A. Al-Hosney, S. Carlos-Cuellar, J. Baltrusaitis, and V.H. Grassian, "Heterogeneous uptake and reactivity of formic acid on calcium carbonate particles: a Knudsen cell reactor, FTIR and SEM study," Phys. Chem. Chem. Phys., vol. 7, pp. 3587-3595, 2005.

[20] Z. Cao et al., "Chemical surface modification of calcium carbonate particles with stearic acid using different treating methods," Appl. Surf. Sci. vol. 378 , pp. 320-329, 2016. 
[21] Y. Wicaksono, B. Wisudyaningsih, and T.A. Siswoyo, "Cocrystal of atorvastatin calcium-malonic acid", Proc. of the $1^{\text {st }}$ Int. Conf. on Med. and Health Sci., pp. 75-78, Jember, Indonesia, 2016.

[22] D.J. Tobler et al., "The effect of aspartic acid and glicine on amorphous calcium carbonate (ACC) structure, stability and crystallization," Proc. Earth and Planet. Sci., vol. 10, pp.143-148, 2014.

[23] D.J. Hodgson and R.W.Asplund, "Calcium binding to carboxylate residues: synthesis and structure of a new form of calcium malonate," In. Chem., vol. 29, pp. 3615-3618, 1990.
[24] M. Patowary, K. Pathak, and R. Ananthakrishnan, "A facile preparation of superhydrophobic and oleophilic precipitated calcium carbonate sorbent powder for oil spill clean-ups from water and land surfaces," RSC Adv., vol. 5, pp. 79852-79859, 2015.

[25] M. Sadeghi and M.H. Husseini, A Novel Method for the Synthesis of $\mathrm{CaO}$ Nanoparticle for the Decomposition of Sulfurous Pollutant," J. of Appl. Chem. Res., vol. 7, pp. 39-49, 2013. 